\title{
Comparison of Free Range Broiler Chicken Strains Raised in Confined or Semi-Confined Systems ${ }^{1}$
}

Q Author(s)
Santos $\mathrm{AL}^{3}$
Sakomura $\mathrm{NK}^{2}$
Freitas $\mathrm{ER}^{3}$
Fortes $\mathrm{CMS}^{3}$
Carrilho ENVM²
1 Part of Master Thesis from first author at
UNESP/FCAV. Jaboticabal, SP.
2 Professor, Faculdade de Ciências Agrárias e
Veterinárias, UNESP/FCAV. Jaboticabal, SP.
3 Graduate student, Animal Science,
Faculdade de Ciências Agrárias e
Veterinárias, UNESP/FCAV. Jaboticabal, SP.

\section{Mail Address}

Prof $^{a}$ Dr $^{\text {a Nilva K. Sakomura }}$

Faculdade de Ciências Agrárias e Veterinárias - FCAV/UNESP

Departamento de Zootecnia.

Via de Acesso Prof. Paulo Donato Castellane,

s/n - Zona Rural

14.870-000. Jaboticabal, SP

e-mail: sakomura@fcav.unesp.br

or

Andréa Luciana dos Santos

Faculdade de Zootecnia e Engenharia de

Alimentos - FZEA/USP

Departamento de Zootecnia (ZAZ)

Av: Duque de Caxias, 225

Jardim Elite

13.635-900. Pirassununga, SP

e-mail: andrealsfia@ig.com.br

\section{Keywords}

Growth curve, ISA Label, meat quality, Paraíso Pedrês, raising system

\section{ABSTRACT}

The present study was carried out to compare the growth curve, performance and carcass yield of two broiler strains, Paraíso Pedrês (PP) and ISA Label (ISA), raised in confined or semi-confined systems. It was used a completely randomized design with five replicates, consisting of 20 and 29 birds in semi-confined and confined systems, respectively. Semi-confined birds had free access to pasture at 28 days of age. Performance data were recorded weekly by building growth curves as well as calculating the growth rate. After reaching the recommended body weight $(2.5 \mathrm{~kg})$, male birds were slaughtered for physicochemical analysis of carcass, parts and organs. Semi-confined PP and ISA birds showed higher growth potential, higher weight gain, lower feed intake and better feed-to-gain ratio than confined birds. No interactions were observed for carcass yield and meat quality characteristics. Males presented higher yields of feet, drumstick, thigh, drumstick + thigh, and heart, while females presented higher breast and abdominal fat yield. Breast meat from ISA Label birds was more yellowish than from PP, whereas less soft meat was observed in semi-confined birds.

\section{INTRODUCTION}

The demand of consumers for different poultry products has influenced changes in commercial poultry husbandry (Gessulli, 1999; Vercoe et al., 2000), and lead to increased development (Verbeke \& Viane, 2000). Society segments have shown great interest in production systems, animal welfare (Von Borell \& Van Den Weghe, 1999; Verbeke \& Viane, 2000) and quality of life (Blokhuis et al., 2000). This resulted in changes that guarantee to consumers choices of new products (Blokhuis et al., 2000; Fraser, 2001).

Confined systems lead to animal stress (Jones \& Millis, 1999), resulting in physiological and behavioral responses (Marin et al., 2001) and poor performance (Mendl, 1999). Changes in the raising systems, which decrease stress conditions and allowing selection of strains that may increase comfort and bird welfare, furthermore, increasing zootechnical performance (Blokhuis et al., 2000; Silva Man et al., 2002). Based on these advantages, birds have been raised in semi-confined systems. This new approach has led the Ministry of Agriculture to implement legal policies concerning the criteria for the production, supply, processing, packaging, distribution, and certification of bird quality (DOI/ DIPOA 007/99 of 05/19/1999).

Parameters such as environmental and nutritional conditions, age, strain and sex may influence meat poultry quality and yield (Silva \& Nakano, 1998). An adequate adjustment of the nutritional level for broiler chickens requires the knowledge on body composition and bird growth potential, and will be followed by increased performance and 
profits (Hruby et al., 1996). Therefore, growth curves may help to define specific nutritional programs and optimal age at slaughter.

The aim of this research was to evaluate the effect of raising systems (confined and semi-confined) on the growth and performance of free-range broiler chicken strains, as well as on meat quality, carcass yield, and yields of parts and organs.

\section{MATERIAL AND METHODS}

This experiment was carried out at the Poultry Facilities of Faculdade de Ciências Agrárias e Veterinárias - FCAV, UNESP, Jaboticabal, São Paulo, Brazil. A completely randomized design was used, with eight treatments and five replicates per treatment. The treatments were established in a $2 \times 2 \times 2$ factorial arrangement ( 2 strains; 2 sexes; 2 raising systems).

Two meat-type broiler strains were used: Paraíso Pedrês (PP) and ISA Label - ISA JA 57 (ISA). There were 490 birds of each strain, and half of each sex. Two hundred and ninety birds of each strain were housed in a confined system and 200 in a semi-confined system.

In the confined system, one-day-old birds were placed in pens of open poultry houses. In this system, 145 birds of each sex and strain were divided in five replicates of 29 birds. Semi-confined birds were placed in 20 paddock areas of $75 \mathrm{~m}^{2}$, which were subdivided into pasture $\left(71.25 \mathrm{~m}^{2}\right)$ and a covered area $\left(3.75 \mathrm{~m}^{2}\right)$ for feeding and resting purposes. In this system, 100 birds from each sex and strain were divided into five replicates of 20 birds. The birds were kept under the covered area from 7:00 pm to 7:00 am and had free access to pasture after 28 days of age.

Birds of both systems were fed the same diet, composed of corn, soybean meal, soybean oil, limestone, calcium phosphate, salt, and mineral and vitamin mixture. The diets were formulated based on the chemical composition of ingredients and broiler nutritional requirements proposed by Rostagno et al. (2000). Birds received feed and water ad libitum throughout the experimental period. Diet levels were $2900 \mathrm{kcal} \mathrm{ME} / \mathrm{kg}$ and $20.69 \% \mathrm{CP}$ from 1 to 21 days; $3000 \mathrm{kcal} \mathrm{ME} / \mathrm{kg}$ and $18.68 \%$ CP from 22 to 49 days; $3100 \mathrm{kcal} \mathrm{ME} / \mathrm{kg} 17.43 \% \mathrm{CP}$, from 50 to 77 days and $3150 \mathrm{kcal} \mathrm{ME} / \mathrm{kg}$ and $17.438 \%$ CP from 78 to 105 days.

Maximum and minimum mean ambient temperatures during the fifteen-week experimental period were $34.2^{\circ} \mathrm{C}$ and $25.3^{\circ} \mathrm{C}$, respectively, in the confined system, and $33.4^{\circ} \mathrm{C}$ and $23.9^{\circ} \mathrm{C}$, respectively, in the semi-confined system. Maximum and minimum relative humidity was 78.9 and $47.9 \%$ in the confined system and 85.5 and $52.0 \%$ in the semi-confined system.

Birds and diets were weighed weekly to determine mean body weight (g), weight gain (g/bird), feed intake (g/bird), and feed-to-gain ratio. When birds had attained commercial body weight $(2.5 \mathrm{~kg}$ for males), three females and three males per replicate were fasted for 12 hours and then slaughtered. The age at slaughter was 63 and 77 days old for Paraíso Pedrês and ISA Label, respectively. Broilers were slaughtered by cervical dislocation and bled. Carcasses were immersed in hot water $\left(60^{\circ} \mathrm{C}\right)$ for $20 \mathrm{~s}$ prior to plucking, followed by manual evisceration and removal of the abdominal fat (gizzard fat + abdominal fat). After pre-chilling in water at $20^{\circ} \mathrm{C}$ for $30 \mathrm{~min}$, chilling was performed at zero to $8{ }^{\circ} \mathrm{C}$ for $15 \mathrm{~min}$. Carcasses and parts were weighed to calculate carcass yield, and the yields of breast drumstick, thigh, drumstick + thigh, wings, back, feet, head + neck, abdominal fat, and organs (intestines, liver, gizzard, heart and proventriculus). Carcass yield was calculated as the ratio between the cold carcass (without legs, head, and neck) and weight after fasting. Breast, drumstick, thigh, drumstick + thigh, wings, and back yield (\%) were calculated as the ratio between the weight of each part and cold carcass weight. Percentages of feet, head + neck, intestines, liver, gizzard, heart, and proventriculus were obtained by the ratio between the weight of each part and the weight after fasting.

Two breasts of each parcel were randomly chosen for meat quality analysis and the meat was refrigerated for 24 hours. Physicochemical characteristics of breast muscle samples, such as water holding capacity, $\mathrm{pH}$, water-cooking losses, texture, and meat color were evaluated. Cooking losses were calculated using the weight of samples before and after cooking in water bath at $70^{\circ} \mathrm{C}$ for 90 min (Purchas cited by Silva Sobrinho, 1999). Shearing force was determined using a Texture Analyzer and a Warner-Bratzler device, which measures shearing $(\mathrm{kg})$. Samples at room temperature $(1.5 \mathrm{~cm}$ long) were placed in the analyzer to determine the maximum force needed to cut using two parallel scalpel blades $1 \mathrm{~cm}$ apart.

Water holding capacity was determined according to the modified method described by Silva Sobrinho (1999). Meat samples (2.0 g) were placed on paper filter (Wattman \#1, $11 \mathrm{~mm}$ diameter) and between two acrylic plates, over which a $10-\mathrm{kg}$ weight was laid for $5 \mathrm{~min}$. The results were expressed as percentage of water released during the pressing process. 
A Colorimeter (Minolta) was used to determine color. The system employs three measures: $L^{*}$ coordinate (black/white) for lightness, a* (green/red) for red content, and b* (blue/yellow) for yellow (Miltenburg et al., 1992; Simões \& Ricardo, 2000). pH was measured in breast muscles and chilled carcasses (24 h after slaughter) using a pHmeter (IpHPJ model, Johnis).

Initially, the Spline linear regression model was used to fit the growth curves. However, this model did not represent the best fit for the potential growth curves. Therefore, Gompertz non-linear growth model (Gompertz, 1925) was used and fitted the data better than the Spline model, especially for the inflection point of the curve. Growth curves were developed based on mean body weight using the formula:

$$
P t=P_{m} \cdot \exp \cdot\left(-\exp .\left(-b .\left(t-t^{*}\right)\right)\right)
$$

where:

$P t=$ weight $(\mathrm{g})$ of animal at $\mathrm{t}$ time, expressed as function of $P_{m}$;

$P_{m}=$ mature weight $(g)$;

$b=$ maturity constant (per day);

$t^{*}=$ time (days) for maximum growth rate.

Thereafter, growth rates were calculated (g/day) according to $t$ time, estimated by equation derivatives. Gompertz function and its parameters were fitted to data using the STATISTICA software (STATISTICA, 1996).

Performance, carcass yield, and meat quality data were analyzed using ANOVA-Statistical Analysis System (6.12 version, SAS, 1989) according to the following model:

$$
\begin{aligned}
& Y=u+S_{i}+L_{j}+X_{k}+\left(S^{\prime} L\right)_{i j}+\left(S^{\prime} X x\right) I K+\left(L^{\prime} X x\right)_{j k} \\
& +\left(S^{\prime} L X x\right)_{i j k}=E_{i j k l}
\end{aligned}
$$

Where:

$\mathrm{u}=$ overall mean;

$S_{i}=$ raising system effect $i(i=1,2)$;

$L_{i}=$ strain effect $j(j=1,2)$;

$X_{x k}=$ sex effect $k(k=1,2)$;

$(\mathrm{S} X \mathrm{~L})_{i .}=$ interaction between $\mathrm{i}$ system and $\mathrm{j}$ strain;

$\left(S^{\prime} X \mathrm{X}\right)_{i \mathrm{k}}=$ interaction between $\mathrm{i}$ system and $\mathrm{k}$ sex;

$\left(L^{\prime} X x\right)_{j k}=$ interaction between $\mathrm{j}$ system and $k$ sex;

$\left(S^{\prime} L^{\prime} X \times 0_{i j k}=\right.$ interaction between i system, j strain, and k sex;

$\mathrm{E}_{\mathrm{ijkl}}=$ error associated to each observation.

Means were compared using Tukey's Test (5\%).

\section{RESULTS AND DISCUSSION}

\section{Growth curves}

The parameters estimated using the Gompertz

\begin{tabular}{|c|c|c|}
\hline Parameters & Males & Female \\
\hline \multicolumn{3}{|c|}{ Paraíso Pedrês - confined } \\
\hline$P^{1}(g)$ & 4764 & 4222 \\
\hline$b^{2}$ (per day) & 0.0318 & 0.0264 \\
\hline$t^{* 3}$ (days) & 44 & 48 \\
\hline$r^{2}$ & 0.99 & 0.99 \\
\hline \multicolumn{3}{|c|}{ ISA Label - confined } \\
\hline$P_{m}^{1}(g)$ & 4320 & 3136 \\
\hline$b^{2}$ (per day) & 0,0280 & 0.0237 \\
\hline$t^{* 3}$ (days) & 52 & 53 \\
\hline$r^{2}$ & 0.99 & 0.98 \\
\hline \multicolumn{3}{|c|}{ Paraíso Pedrês - semi-confined } \\
\hline$P_{m}^{1}(g)$ & 5291 & 4379 \\
\hline$b^{2}$ (per day) & 0.0291 & 0.0257 \\
\hline $\mathrm{t}^{* 3}$ (days) & 48 & 50 \\
\hline$r^{2}$ & 0.99 & 0.99 \\
\hline \multicolumn{3}{|c|}{ ISA Label - semi-confined } \\
\hline$P_{m}^{1}(g)$ & 4347 & 3247 \\
\hline$b^{2} 2$ (per day) & 0.0278 & 0.0237 \\
\hline$t^{* 3}$ (days) & 52 & 53 \\
\hline$r^{2}$ & 0.99 & 0.99 \\
\hline
\end{tabular}
function (Table 1) showed higher growth potential for males than for females in both raising systems.

$1-P_{m}(k g)=$ mature weight. $2-b$ (per day $)=$ maturity rate. $3-t^{*}$ (day) = age at maximum growth rate. Gompertz equation: $P=P_{M}{ }^{*} \exp$

$(-\exp (-b *($ age-t) ))

High estimates for mature weight were observed in semi-confined PP birds. However, for both strains, the semi-confined system provided better growth potential, which may be due to a higher tolerance to this raising system, in addition to higher welfare According to Blokhouis et al. (2000) and Silva Man et al., (2002), changes in the raising environment in order to reduce stress, together with selection of more resistant birds, may contribute to animal welfare and, consequently, better performance. Therefore, these facts may explain the higher growth of semi-confined birds and the good performance of PP strain.

In both systems, maturity rates $\left(b^{*}\right)$ of live weight for PP males and females were higher than the estimates of growth rates of ISA males and females, which indicates different growth potential of PP birds. Raising systems influenced $b^{*}$ in both strains, so that confined birds exhibited more accelerated $b^{*}$. Fialho (1999) observed that changes on $b^{*}$ altered the growth curve. Higher values of $b^{*}$ lead to well distributed 
Santos AL, Sakomura NK, Freitas ER, Fortes CMS, Carrilho ENVM
Comparison of Free Range Broiler Chicken Strains Raised in Confined or Semi-Confined Systems ${ }^{1}$ growth along time. Similar results occurred analyzing maximum growth rate $\left(t^{*}\right)$ between strains PP and ISA in both systems and estimated t* values for PP birds were 44 and 48 days of age for confined males and females, respectively, and 48 and 50 days of age for semi-confined males and females, respectively. Estimated $t$ * values for ISA birds were 52 days for males and 53 days for females in both systems.

Table 1 shows the values of mature weight for semiconfined PP males $(5291 \mathrm{~g})$ and females $(4379 \mathrm{~g})$ and ISA males (4347g) and females (3247g). Maximum growth rate $\left(t^{*}\right)$ occurred at 48 and 52 days for males and 50 and 53 days for females of PP and ISA strains, respectively. Figueiredo et al. (2003b) evaluated birds raised in semi-confined system and reported mature weight of $3961 \mathrm{~g}$ and $3471 \mathrm{~g}$ and maximum growth rate $\left(t^{*}\right)$ of 49.08 and 49.3 days for males and females of Embrapa 041 and ISA strains, respectively.

Semi-confined PP male birds showed the highest growth potential, so that the growth was more accelerated after 10 weeks of age due to welfare. The older birds exhibited lower growth rates and weight gain. The standard acceleration changing point or the inflection point in the curve is the point where the curve changes from concave to convex.

Figures 1 and 2 show the growth curve rates obtained from growth curves. The maximum rate of gain in semi-confined PP was $56.69 \mathrm{~g} /$ day at 48 days for males and $41.35 \mathrm{~g} /$ day at 50 days of age for females. In the confined system, maximum rate gain was $55.68 \mathrm{~g} /$ day at 44 days and $40.98 \mathrm{~g} /$ day at 48 days for males and females, respectively. Additionally, in semi-confined ISA Label birds, this parameter was $44.49 \mathrm{~g} /$ day at 52 days of age for males and $28.28 \mathrm{~g} /$ day for females, whereas in confined ISA Label it was $44.52 \mathrm{~g} /$ day for males and $27.31 \mathrm{~g} /$ day for females.

Gompertz curve characteristics are around the inflexion point, where maximum growth rate is achieved (Fialho, 1999). In practice, the exact inflexion point is not important, but the length of time during which the growth rate is constant, since the highest deposition of meat in broilers occurs at this point. The convex segment of the curve coincides with the period during which there is a progressive reduction in protein deposition rate, but the body fat growth still occurs until certain age. Afterwards, fat growth also declines and the curve reaches zero, which means that the adult weight has been attained. Generally, PP exhibited higher growth potential than ISA and semi-confined systems allowed higher growth potential for both strains, which agrees with results reported by Figueiredo et al. (2003b).

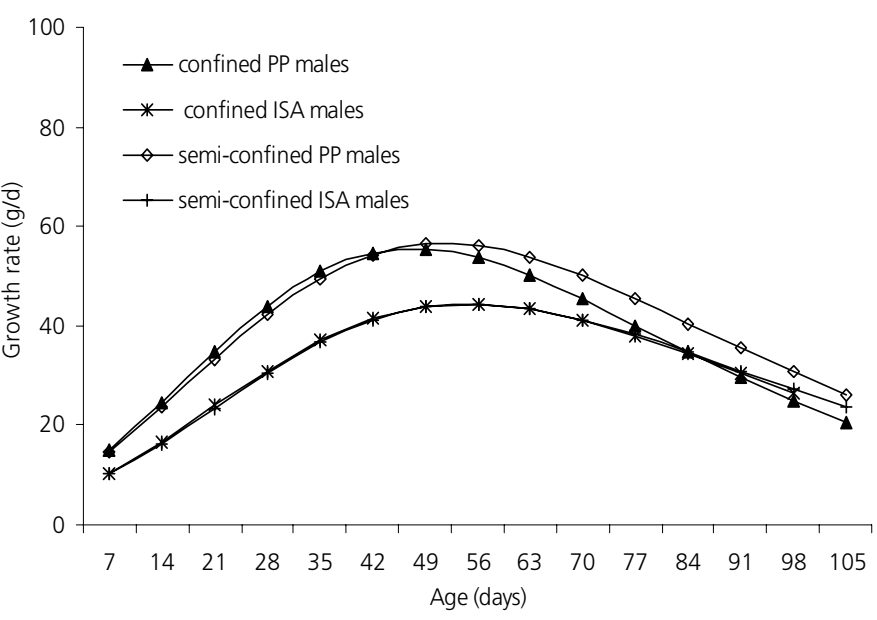

Figure 1 - Growth rates of ISA Label (ISA) and Paraíso Pedrês (PP) males.

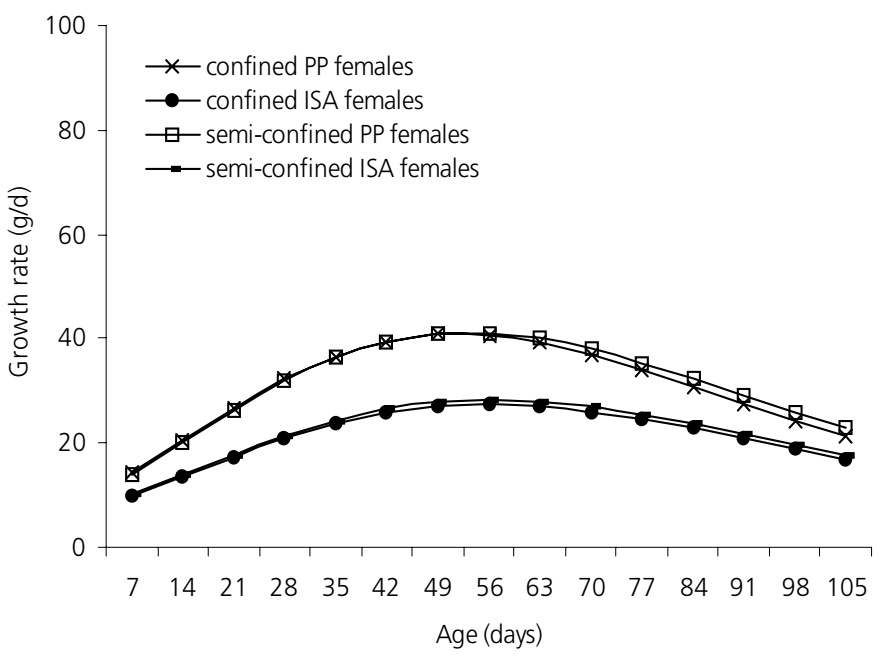

Figure 2 - Growth rates of ISA Label (ISA) and Paraíso Pedrês (PP) females.

\section{Performance}

The raising system, strain, and sex had significant effect $(p<0.05)$ on weight gain, feed intake and feedto-gain ratio. However, the results were significantly influenced by interactions between system and strain and between sex and strain. Performance data of both strains are shown in Table 2.

Body weight gain for both strains in the semiconfined system was higher than that in the confined system, what may be due to bird comfort and welfare. According to Silva \& Silva. (2001), changes on the raising environment, which decrease stressful conditions and select more resistant strains, may have improved birds' comfort, welfare and performance. 
Paraíso Pedrês birds exhibited better feed-to-gain ratio than ISA, in both raising systems. These results are in agreement with findings reported for four freerange broiler strains with free access to pasture and fed commercial diets ad libitum (Carrijo et al., 2002). The authors also reported higher BWG in PP than Carijó Pesado and ISA, but there were no differences from Vermelho Pesado strain (Carrijo et al., 2002).

An interaction was seen between raising system and strain on feed intake in birds from 1 to 21 days of age and from 1 to 49 days old (Table 2). In the same periods, ISA birds showed no differences due to the raising system. However, confined birds exhibited higher feed intake from 1 to 77 days old and from 1 to 105 days old. Such pattern was similar to PP in all periods. Considering the fact that birds raised in the semi-confined system had free access to pasture at 28 days of age, feed intake up to 21 days old could be similar to the feed intake of birds in the confined system. Other explanation can be based on environmental effects, but such effects could not be identified. On the other hand, free access to pasture allows birds to eat plants and insects, which can decrease feed intake.

Paraíso Pedrês birds exhibited better feed-to-gain ratio than ISA in all periods. This can be explained by the high growth potential of PP and, consequently, high feed intake. Rabello (1996) found greater initial growth potential and higher feed intake for Hubbard birds in comparison with other strains.

There was interaction between raising system and strain on feed intake from 1 to 21 days of age. At this period, similar feed-to-gain ratio was observed for both strains in the confined system. However, semi-confined
PP birds presented better feed-to-gain ratio than ISA birds, due to significant differences on weight gain and feed intake. Therefore, PP exhibited better feed-togain ratio than ISA. These results are not in agreement with Carrijo et al. (2002), who reported no differences between the two strains.

Semi-confined birds exhibited better feed-to-gain ratio in all periods, considering the system effect, associated to lower feed intake and higher weight gain. Interaction between sex and strains for PP and ISA are presented in Table 3.

PP and ISA males exhibited higher mean weight gain $(p<0.05)$ and growth potential than females. Both PP males and females showed higher weight gain $(p<0.05)$ than ISA. Sex influenced feed-to-gain ratio $(p<0.05)$ and males had better feed performance than females. Males exhibited higher growth rates than females, except for ISA from 1 to 21 days, which was explained by a bird that was wrongly sexed. The error was corrected at 21 days of age.

\section{Yields of carcass, parts, and organs}

Mean yields of carcass, parts, and organs, and the physicochemical parameters are shown in Table 4. No interaction was observed for these variables $(p<0.05)$.

No differences in yields of feet, carcass, breast, drumstick, thigh, drumstick + thigh, wings, and back and abdominal fat was observed between strains. On the other hand, head + neck ratio, as well as liver and proventriculus relative weights were higher in PP than ISA. The age at slaughter is often used to determine body weight, which is different for each strain and may influence yields of carcass and parts in broiler chickens.

\begin{tabular}{|c|c|c|c|c|c|c|}
\hline \multirow{2}{*}{$\begin{array}{l}\text { 1-21 days } \\
\text { Strain }\end{array}$} & \multicolumn{2}{|c|}{ Weight gain (g) } & \multicolumn{2}{|c|}{ Feed intake $(\mathrm{kg})$} & \multicolumn{2}{|c|}{ Feed-to-gain ratio } \\
\hline & Confined & Semi-confined & Confined & Semi-confined & Confined & Semi-confined \\
\hline Paraíso Pedrês & $526^{A b}$ & $653^{\mathrm{Aa}}$ & $0.85^{\mathrm{Aa}}$ & $0.69 A b$ & $1.62^{\mathrm{Ab}}$ & $1.06^{\mathrm{Aa}}$ \\
\hline ISA Label & 359 в b & $458^{\mathrm{B} \mathrm{a}}$ & $0.59^{\mathrm{B} a}$ & $0.59 \mathrm{Ba}$ & $1.64^{\mathrm{Ab}}$ & $1.30^{\mathrm{B} \mathrm{a}}$ \\
\hline \multicolumn{7}{|l|}{ 1-49 days } \\
\hline Paraíso Pedrês & 1774 & 1865 & $4.04^{\mathrm{Aa}}$ & $3.66^{\mathrm{Ab}}$ & 2.28 & 1.96 \\
\hline ISA Label & 1233 & 1328 & $2.76^{\mathrm{Ba}}$ & $2.64^{\mathrm{B} \mathrm{a}}$ & 2.27 & 2.00 \\
\hline CV $(\%)$ & 3.47 & & 4.36 & & 4.14 & \\
\hline \multicolumn{7}{|l|}{ 1-77 days } \\
\hline Paraíso Pedrês & 2912 & 3051 & $8.24^{\mathrm{Aa}}$ & $7.29^{\mathrm{Ab}}$ & 2.85 & 2.39 \\
\hline ISA Label & 2142 & 2231 & $6.11^{\mathrm{Ba}}$ & $5.57^{\mathrm{B} \mathrm{b}}$ & 2.93 & 2.53 \\
\hline CV (\%) & 3.0 & & 3.36 & & 2.65 & \\
\hline \multicolumn{7}{|l|}{ 1-105 days } \\
\hline Paraíso Pedrês & $3748^{A b}$ & $4021^{\mathrm{Aa}}$ & 12.17 & 11.84 & 3.25 & 2.95 \\
\hline ISA Label & $2874^{\mathrm{B} \mathrm{b}}$ & $3003^{\mathrm{B} \mathrm{a}}$ & 9.56 & 9.14 & 3.39 & 3.06 \\
\hline CV (\%) & 3.18 & & 4.0 & & 3.38 & \\
\hline
\end{tabular}

Means followed by different capital letters in the columns and small letters in the rows are significantly different according to Tukey's test $(p<0.05)$. 


\begin{tabular}{|c|c|c|c|c|c|c|}
\hline \multirow[b]{2}{*}{ 1-21 days } & \multicolumn{2}{|c|}{ Weight gain (g) } & \multicolumn{2}{|c|}{ Feed intake $(\mathrm{kg})$} & \multicolumn{2}{|c|}{ Feed-to-gain ratio } \\
\hline & & & & & & \\
\hline Strains & Male & Female & Male & Female & Male & Female \\
\hline Paraíso Pedrês & $625^{\mathrm{Aa}}$ & $554^{A b}$ & $0.80^{\mathrm{Aa}}$ & $0.74^{A b}$ & 1.31 & 1.37 \\
\hline ISA Label & 395 в а & $422^{\mathrm{B} \mathrm{b}}$ & $0.58^{\mathrm{Ba}}$ & $0.61^{\text {в а }}$ & 1.48 & 1.46 \\
\hline \multicolumn{6}{|l|}{ 1-49 days } & \\
\hline Paraíso Pedrês & $2012^{\mathrm{Aa}}$ & $1628^{A b}$ & $4.17^{\mathrm{Aa}}$ & $3.53^{\mathrm{Ab}}$ & $2.08^{\mathrm{Ba}}$ & $2.17^{\mathrm{Aa}}$ \\
\hline ISA Label & $1475^{\mathrm{Ba}}$ & $1086^{\mathrm{Bb}}$ & $2.89 \mathrm{Ba}$ & $2.50^{\mathrm{Bb}}$ & $1.96 \mathrm{Aa}$ & $2.31^{\mathrm{Bb}}$ \\
\hline CV (\%) & 3.47 & & 4.36 & & 4.14 & \\
\hline \multicolumn{7}{|l|}{ 1-77 days } \\
\hline Paraíso Pedrês & $3375^{\mathrm{Aa}}$ & $2588^{A b}$ & 8.46 & 7.08 & $2.51^{\mathrm{Aa}}$ & $2.74^{A b}$ \\
\hline ISA Label & $2630^{\mathrm{Ba}}$ & $1744^{B D}$ & 6.46 & 5.22 & $2.46^{\mathrm{Aa}}$ & $3.00^{B b}$ \\
\hline CV $(\%)$ & 3.0 & & 3.36 & & 2.65 & \\
\hline \multicolumn{7}{|l|}{$1-105$ days } \\
\hline Paraíso Pedrês & $4230^{\mathrm{Aa}}$ & $3559^{A b}$ & $12.69 \mathrm{Aa}$ & $11.32^{\mathrm{Ab}}$ & $3.00^{\mathrm{Aa}}$ & $3.20^{\mathrm{Ab}}$ \\
\hline ISA Label & $3452^{\mathrm{Ba}}$ & $2424^{B b}$ & $10.31^{\mathrm{B} \mathrm{a}}$ & $8.39^{\mathrm{Bb}}$ & $2.99 \mathrm{Aa}$ & $3.47^{\mathrm{Bb}}$ \\
\hline CV $(\%)$ & 3.18 & & 4.0 & & 3.38 & \\
\hline
\end{tabular}

Means followed by different capital letters in the columns and small letters in the rows are significantly different according to Tukey's test $(p<0.05)$.

According to the growth curves already presented, the growth rates were different. PP exhibited higher growth rate than ISA, therefore achieving earlier the ideal weight for slaughter. Additionally, the standardization of slaughter weight to $2.5 \mathrm{~kg}$ of live weight resulted in no differences between strains considering both carcass yield and parts yield. However, ISA birds should be slaughtered later than PP to produce the same yields of carcass and parts. Figueiredo et al. (2003a) observed that ISA birds had smaller carcass size and less abdominal fat than Ross and EMBRAPA 041 strains when slaughtered at the same age.

As for sex effect (Table 4), males exhibited higher feet and heart relative weights, while females showed higher breast and abdominal fat yields. Similar results have been reported by Figueiredo et al. (2003a). Sex had no effect on carcass yield, corroborating results reported by Pescatore et al. (1992). On the other hand, Mendes et al. (1993) and Politi et al. (1993) reported higher carcass yield in females. Besides, males had higher heart relative weight than females. The present results are not in agreement with Figueiredo et al. (2002), who reported bigger or heavier internal organs in males than in females, but higher weight percentages in females than in males.

Raising system influenced gizzard weight. Relative gizzard weight was higher in semi-confined birds (about $2.3 \%$ of weight after fasting) than in confined birds (2.0\% weight after fasting). This result may be attributed to a highly functional gizzard. The intake of fibers and grit might have resulted in greater development of this organ. There were no differences in gizzard percentage between strains; however, females had greater gizzard relative weight than males. Similarly, Rabello (1996) observed no differences in gizzard relative weight between sexes, whereas Figueiredo et al. (2002) have reported that males from four different strains had higher gizzard relative weights.

\section{Meat quality}

There were no interactions between strains and raising systems on meat quality parameters (Table 4). However, strains influenced $(p<0.05) b *$ color (yellowish), $\mathrm{pH}$, and cooking losses. Sex influenced $\mathrm{L}^{*}$ color (luminosity - black/white), and the raising system affected breast meat shearing force. Meat color is an important quality parameter for consumers while choosing poultry meat, and free range birds usually have acceptable color. $L^{*}$ coordinate and $a$ * in the breast meat were not different between strains, but ISA presented higher $b$ * values (intense yellow meat color) than PP.

Post mortem alterations include changes in $\mathrm{pH}$, which ranges from 7.3 to 7.5 in live animals. After death, $\mathrm{pH}$ decreases until 5.4 within 2 to $8 \mathrm{~h}$ after bleeding, when rigor mortis takes place. During this process, lactic acid is formed from glycogen, which decreases meat $\mathrm{pH}$, and it becomes tender and tastier, with its characteristic smell (Cañeque et al. 1989). pH values ranged from 5.6 to 5.7 in meat from PP and ISA birds, which are similar to values previously reported. This parameter was influenced by strain and sex. ISA 


\begin{tabular}{|c|c|c|c|c|c|c|c|c|c|}
\hline \multirow{4}{*}{ Variables } & \multicolumn{8}{|c|}{ Variables } & \multirow{4}{*}{ CV (\%) } \\
\hline & \multicolumn{4}{|c|}{ Paraíso Pedrês } & \multicolumn{4}{|c|}{ ISA Label } & \\
\hline & \multicolumn{2}{|c|}{ Confined } & \multicolumn{2}{|c|}{ Semi-confined } & \multicolumn{2}{|c|}{ Confined } & \multicolumn{2}{|c|}{ Semi-confined } & \\
\hline & M & $\mathbf{F}$ & $\mathbf{M}$ & $\mathbf{F}$ & $\mathbf{M}$ & $\mathbf{F}$ & $\mathbf{M}$ & $\mathbf{F}$ & \\
\hline Carcass yield $(\%)^{1}$ & 72.4 & 72.2 & 73.3 & 72.5 & 71.8 & 71.7 & 72.3 & 71.9 & 3.2 \\
\hline Breast yield $(\%)^{2}$ & 28.5 & 29.3 & 28.6 & 29.6 & 28.0 & 29.2 & 28.4 & 30.0 & 2.6 \\
\hline Thigh yield $(\%)^{2}$ & 15.0 & 14.4 & 14.8 & 14.7 & 15.5 & 14.8 & 15.4 & 14.4 & 5.3 \\
\hline Upper thigh yield $(\%)^{2}$ & 15.8 & 15.5 & 16.3 & 16.1 & 16.2 & 15.1 & 16.2 & 15.3 & 2.8 \\
\hline Thigh + upper thigh yield $(\%)^{2}$ & 30.8 & 29.9 & 31.1 & 30.9 & 31.7 & 31.1 & 31.6 & 29.7 & 2.9 \\
\hline Wings $(\%)^{2}$ & 12.3 & 12.8 & 12.1 & 12.5 & 12.8 & 12.6 & 12.6 & 12.3 & 4.0 \\
\hline $\operatorname{Back}(\%)^{2}$ & 26.2 & 27.6 & 26.8 & 26.8 & 26.7 & 26.4 & 26.4 & 26.6 & 4.3 \\
\hline Feet $(\%)^{1}$ & 4.2 & 3.4 & 4.2 & 3.5 & 4.0 & 3.9 & 4.1 & 3.4 & 6.7 \\
\hline Head + neck $(\%)^{1}$ & 7.0 & 6.8 & 7.1 & 7.3 & 6.8 & 6.5 & 6.9 & 6.8 & 5.4 \\
\hline Abdominal fat $(\%)^{2}$ & 2.8 & 3.6 & 2.5 & 3.2 & 2.5 & 3.1 & 2.3 & 3.2 & 20.0 \\
\hline Liver $(\%)^{1}$ & 1.3 & 1.6 & 1.5 & 1.6 & 1.3 & 1.6 & 1.3 & 1.5 & 8.4 \\
\hline Gizzard (\%) & 1.9 & 2.0 & 2.0 & 2.3 & 1.9 & 2.1 & 2.2 & 2.6 & 13.6 \\
\hline Heart $(\%)^{1}$ & 0.4 & 0.4 & 0.5 & 0.4 & 0.5 & 0.4 & 0.5 & 0.4 & 12.0 \\
\hline Intestines (\%) & 3.3 & 3.4 & 3.4 & 3.5 & 3.1 & 3.3 & 2.8 & 3.4 & 12.6 \\
\hline Proventriculus (\%) & 0.3 & 0.3 & 0.3 & 0.4 & 0.3 & 0.3 & 0.3 & 0.3 & 16.8 \\
\hline L*color & 48.6 & 50.0 & 50.8 & 50.5 & 49.3 & 50.2 & 48.9 & 51.3 & 3.3 \\
\hline$a^{*}$ color & 3.9 & 3.3 & 4.9 & 3.0 & 3.0 & 3.5 & 3.6 & 3.4 & 38.6 \\
\hline$b^{*}$ color & 5.7 & 5.4 & 6.0 & 5.3 & 5.2 & 7.5 & 6.4 & 8.6 & 23.4 \\
\hline $\mathrm{pH}$ & 5.7 & 5.7 & 5.7 & 5.8 & 5.6 & 5.5 & 5.7 & 5.6 & 1.3 \\
\hline Shearing force $(\mathrm{kgf} / \mathrm{g})$ & 1.6 & 1.3 & 1.9 & 1.6 & 1.6 & 1.2 & 2.0 & 1.9 & 36.3 \\
\hline Water holding capacity (\%) & 65.5 & 62.7 & 65.7 & 66.2 & 65.1 & 65.4 & 65.4 & 62.2 & 4.4 \\
\hline Cooking losses (\%) & 22.4 & 22.0 & 24.6 & 23.2 & 19.1 & 19.6 & 18.9 & 19.1 & 6.6 \\
\hline
\end{tabular}

(1) $\%$ live weight. (2) $\%$ frozen carcass. Color: $L^{*}=$ lightness; $a^{*}=$ redness; and $b^{*}=$ yellowness.

presented higher $\mathrm{pH}$ than PP (Table 4). Meat from males had higher $\mathrm{pH}(5.69)$ than from females $(5.64)(\mathrm{p}<0.05)$. According to Sãnudo (1992), pH may be influenced by internal factors such as muscle type, species, breed, age, sex, and individual characteristics, and may also be influenced by external factors such as feed, fasting, electrical stimulation and chilling.

Among the organoleptic characteristics, tenderness is considered the most important by consumers, which can be defined as how easy the meat can be chewed or cut. Raising systems did not influence water holding capacity and cooking losses. However, the meat of semi-confined birds was tougher, indicating higher texture and shearing force, which can be explained by exercising during grazing.

Even though no differences were found, birds raised in semi-confined system presented lower water holding capacity and, consequently, meat was less tender than meat of confined birds. Lower water holding capacity indicates losses in the nutritional value through exudates that are released and result in drier and tougher meat (Dabés, 2001). Therefore, semi-confined birds presented better texture, a characteristic that consumers expect. Concerning weight losses at cooking, results corroborate findings reported by Sãnudo (1992), who found weight losses due to the cooking process.

\section{CONCLUSION}

The semi-confined system was more efficient to raise free range birds, resulting in better performance. Paraíso Pedrês showed better growth potential and performance than ISA Label birds. On the other hand, ISA had better qualitative characteristics, such as higher texture and more yellowish meat, which are more adequate to supply the demand of consumers for free range products.

\section{REFERENCES}

Blokhuis HJ, Ekkel ED, Korte SM, Hosper H, Van Reenen CG. Farm animal welfare research in interaction with society. Veterinary Quality 2000; 22(4):217-222

Cañeque V. La canal de cordeiro. In: Producción de Carne de Cordeiro; 1989; México, MEX. México, 1989. 367-436.

Carrijo AS, Menezes GP, Silva MJ, Oliveira MSS, Onselen VJ. Avaliação de Linhagens alternativas na criação de frango tipo caipira. Revista Brasileira Ciencia Avicola. (Campinas) 2002; 4 (supl.): 84.

Dabés AC. Propriedades da carne fresca. Revista Nacional da Carne, São Paulo. 2001; 25 (288):32-40.

Fialho FB. Embrapa Suínos e Aves. (Comunicado técnico) 1999. 237. 

Santos AL, Sakomura NK, Freitas
ER, Fortes CMS, Carrilho ENVM
Figueiredo EPA, Ávila VS, Schimidt Gs, Baroni Jr. W, Colbella A, Piccinin I. Curvas de crescimento de linhagens criadas em sistema alternativo. Revista Brasileira Ciencia Avicola. (Campinas) 2003b; 5 (supl.):111.

Figueiredo EPA, Ávila VS, Bellaver C, Bomm ER, Boff JA, Bassi L. Linhagens e sistema de criação para produção de frangos coloniais. Revista Brasileira Ciencia Avicola (Campinas) 2003a; 5(supl.): 10.

Figueiredo EPA, Rosa OS, Omm ER, Boff Já, Bassi L. Peso e tamanho dos órgãos de diferentes linhagens de frangos de corte. Revista Brasileira Ciência Avícola. (Campinas) 2002; 4(supl.):95.

Fraser D. The "new perception" of animal agriculture legless cows, featherless chickens and a need for genuine analysis. Journal Animal Science 2001; 79(3):634-641.

Gessulli OP. Avicultura alternativa sistema "ecologicamente correto" que busca o bem-estar animal e a qualidade do produto final. Porto Feliz: OPG; 1999. 217.

Gompertz B. On the nature of the function expressive of the law of human mortality and on a new method of determining the value of life contingencies. Transactions of the Philological Society. 1925; (115):513-85.

Hruby M, Hamre ML, Coon N. Non-linear and linear functions in body protein growth. Journal Applied Poultry Research, 1996; 5:09115.

Jones RB, Millis AD. Divergent selection for social reinstatement and behaviors in Japanese quail: effects on sociality and social discrimination. Poultry Avian Biology Research. 1999; 10(4):213223.

Marin RH, Freytes P, Gusman D, Jones RB. Effects of an acute stressor on fear and on the social reinstatement responses of domestic chicks to cage mates and strangers. Applied Animal Behavior Science 2001; 71(1):57-66

Mendes AA, Garcia EA, Gonzáles E. Efeito da linhagem e idade de abate sobre o rendimento de carcaça de frangos de corte. Revista Brasileira Zootecnia. 1993; 22(3):466-472.

Mendl, M. Performing under pressure: stress and cognitive function. Applied Animal Behavior Science. 1999; 65(93):221-224.

Miltenburg GAJ. Relationship between blood hemoglobin, plasma and tissue iron, muscle heme pigment, and carcass color of veal. Journal of Animal Science. (Champaing) 1992; 70(9):2766-2772.

MINISTÉRIO DA AGRICULTURA, PECUÁRIA E ABASTECIMENTO. Ofício Circular DOI/DIPOA 19 de maio de 1999. "Registro do Produto "Ovos Caipira" ou "Ovos Tipo ou Estilo Caipira" ou "Ovos Colonial" ou "Ovos Tipo ou Estilo Colonial". Diário Oficial da União, Brasília, DF, 04 de novembro de 1999.

Pescatore AJ, Cantor $\mathrm{AH}$, Xiangbai $\mathrm{H}$. Processing yield of eight commercial strain crosses of broilers. Poultry Science.1992; 1(supl.): $71-26$.
Comparison of Free Range Broiler Chicken Strains Raised in Confined or Semi-Confined Systems ${ }^{1}$

Politi ES, Varoli Jr JC, Gonzáles E. Efeito da linhagem e sexo sobre o rendimento de carcaça de frangos de corte. Revista Brasileira de Ciência Avícola. (Santos) 1993; 88.

Rabello CBV. Desempenho e características de carcaça de três híbridos de frangos de corte. 1996. 66f. Dissertação (Mestrado em Zootecnia) - Universidade Federal de Lavras - Lavras, 1996.

Rostagno HS, Albino LFT, Donzele JL, Gomes PC, Ferreira AS, Oliveira RF, Lopes DC. Tabelas brasileiras para aves e suínos (composição de alimentos e exigências nutricionais). Viçosa; 2000.141.

Sañudo C. La calidad organoléptica de la carne con especial referencia a la especie ovina: factores que la determinan, metodos de medida y causa de variación. 1992. 117f. Facultad de Veterinaria - Departamento Producción Animal y Ciencia de los Alimentos, Zaragoza, 1992.

SAS Language and procedures: version 6. Cary, 1989. 638.

Silva Man, Hellmeister Filho F, Rosário MF, Martins E, Coelho AAD, Savino VJM, Silva IJ O, Menten JFM. Adaptação de linhagens de galinhas para corte ao sistema de criação semi-intensivo. Revista Brasileira de Ciência Avícola (Campinas) 2002; 4(3):219-225.

Silva Sobrinho AG. Body composition and characteristics of carcass from lambs of different genotypes and ages at slaughter. 1999. 54f. (Lecture report in Sheep Meat Production), Massey University, Palmerston North, 1999.

Silva HG, Silva MJ, In: Encontro Técnico-Ciêntífico do CCET. 2001; Campo Grande. BR. Campo Grande:2001. 7.

Silva RDM, Nakano M. Sistema caipira de criação de galinhas. Piracicaba. O Editor, 1998. 110.

Simões JA, Ricardo R. Avaliação da cor da carne tomando como referência o músculo rectus abdomonalis, em carcaças de borregos leves. Revista Portuguesa de Ciência e Veterinária, Lisboa. 2000; 95 (535):124-127.

Statistica, Version Release 5.1. for Windows, 1996.

Verbeke WAJ; Viane J. Ethnical challenges for livestock production: meeting consumer concerns about meat safely and animal welfare. Journal Agriculture Environment Ethics. 2000; 12(2):41-151.

Vercoe JE, Fitzhugh HA, Von Kaufmann R, Livestock productions systems beyond. Asian - (Australian). Journal Animal Science. 2000; 13(5):411-419.

Von Borell E, Van Den Weghe S. Development of criteria for the assessment of housing systems for cattle, pigs and laying hens relating to animal welfare and environmental impact. Zuchtungskung. 1999; 71(1):8-16. 